\title{
Variability of rock pressure along the length of the working face
}

\author{
Maksim V. Shinkevich ${ }^{1}$ \\ ${ }^{1}$ Institute of Coal, Federal Research Centre of Coal and Chemistry SB RAS, Kemerovo, Russia \\ *e-mail: max-valerich@rambler.ru
}

\begin{abstract}
Introduction. Common deepening of mining causes problems with maintaining the achieved production capacity. The ability of the mechanized supports to withstand rock pressure in such conditions is questioned. Modern supports equipped with pressure sensors will make it possible to control and prevent the negative impact of the increased rock pressure and visualize the results.

Research aim is to determine the rock pressure variation rate along the length of the longwall in order to avoid its negative impact and to plan the capacity of the cutter-loader and load upon the working face in various mining and geological conditions in a more substantiated way.

Methodology. The use of the Surfer software to visualize the processes of displacement and construct the geomechanical structure diagram of the coal-bearing disintegrated rock mass in the form of geomechanical layers hierarchy makes it possible to forecast the sites with the increased rock pressure upon the coal bed and the longwall support.

Results. Timely and well-grounded determination of the sites with the increased rock pressure upon the coal bed and the powered support at the longwall face advance is the technical results of the research. Analysis and discussion. The geomechanical structure diagram shows the sequence of disintegrated rock displacement arches development. Overburden and bearing pressure acts upon the coal bed between the displacement arches and depends on the depth of coal bed occurrence, working face advance speed and the strength of the roof rock. It is the sum of the overburden and bearing pressure that is reflected on the state of the coal bed ahead of the face of the longwall; their impact is wave-like. Summary. The diagram will make it possible to forecast the sites subject to the negative impact of rock pressure along to length of the longwall and improve the effectiveness of coal bed mining by means of more accurate calculation of load upon the working face and the capacity of the cutter-loader, specify the force of cutting machine working elements during coal bed breaking, choose the support of the longwall according to the load-carrying capability, plan some measures to eliminate the negative impact of rock pressure at particular sites, and strengthen the marginal part of the bed in order to reduce visible coal sloughing.
\end{abstract}

Key words: rock pressure; coal bed; enclosing rock mass; rock; longwall face.

Introduction. Within the last decades working areas capacity has increased by a long way. Due to the tendency towards increasing mining depth and increasing gas content of the developed coal beds, the issues of maintaining the achieved coal production levels and further growth of productivity have become relevant. Rock pressure and gas-oil ratio are known to be the main factors restricting effective development of coal fields. It is impossible to develop equipment and technology without taking into account modern knowledge on the processes occurring within the rock mass when cutting the coal beds. Numerous scientists both in Russia [1,2] and abroad [3-8] deal with the issues of coal mining safety. As it has been stated in [9], the processes of displacements and gas emission out of the rock mass are closely connected. It is beyond doubt that investigation of rock pressure generation processes is relevant at the present time. 
Research aim is to determine the rock pressure variation rate along the length of the longwall in order to avoid its negative impact and to plan the capacity of the cutterloader and load upon the working face in various mining and geological conditions in a more substantiated way.

Methodology. Research [10] proved the waviness (nonlinearity) of the geomechanical process as applied to the coal bed mined by the room and pillar method. Conclusion on the nonlinearity of the geomechanical processes is based on the application of gas dynamics methods. Nonlinearity of the working area methanebearing capacity variation has been shown with the period which is incommensurably larger than the caving step of the main roof. The data on the pressure in the posts of the powered support [11] are presented, which also prove the wave-like character of the process, but the area near the face and possible consequences of wave-like rock pressure effects are not considered in details. Reference to the data on pressure in power support posts can be found in the works of foreign authors. Pressure variation wave-like character has been registered but there have been no recommendations on practical implementation of the registered variation of rock pressure. The whole matter comes down to stating the observed features.

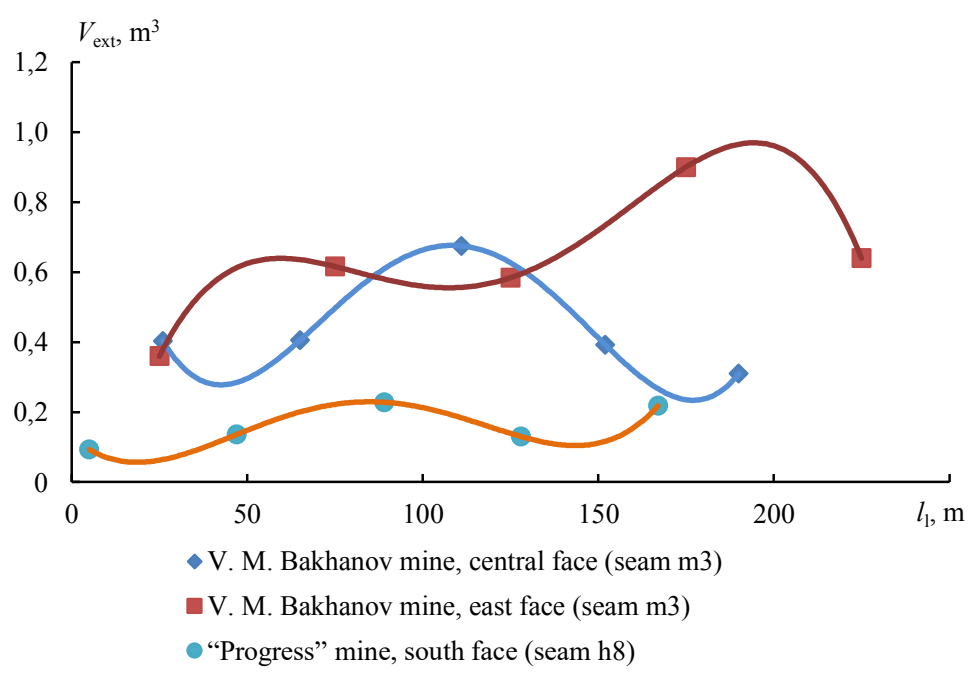

Fig. 1. Sloughed coal volume alternation along the length of the working face Рис. 1. Изменение объема отжатого угля по длине очистного забоя

There are some investigations of rock pressure effect on the coal bed along the length of the working face [12] and on coal massif weakening [13]. Research [14] considers alternation of sloughed coal volume $V_{\text {ext }}$ along the length of the longwall face $l_{1}$ (fig. 1).

It can be seen at fig. 1 that the volume of the sloughed coal along the length of the longwall changes in waves, i.e. rock pressure, which has an effect on the coal bed, is of the wave-like character. Research [15] attributes the wave-like alternation of rock pressure to the technogenic structuring of the rock mass when cutting the coal bed.

Having counted pressure indicators in the posts of the powered support according to the formulae (1)-(3), let us determine the height of the rock layer which has an effect on the support; for this let us accept the mean density of rock equal to $2.5 \mathrm{t} / \mathrm{m}^{3}$ (fig. 2 ). Surfer software is used to construct the pressure area. 
The force response of the powered support posts, MN:

$$
P_{p}=P_{p 1} S_{p 1}+P_{p 2} S_{p 2}
$$

posts pressure distributed along the area of the roof timber, MPa:

$$
P_{r}=P_{p} / S_{r},
$$

the height of the rock layer which has an effect on the support, m:

$$
h_{\text {layer }}=P_{r} / 0.025 \text {, }
$$

where $P_{p 1}, P_{p 2}$ - fluid pressure in the posts of the powered support, $\mathrm{MPa} ; S_{p 1}, S_{p 2}-$ the squares of the powered support posts piston, $\mathrm{m}^{2} ; S_{r}-$ the square of the roof timber, $\mathrm{m}$.

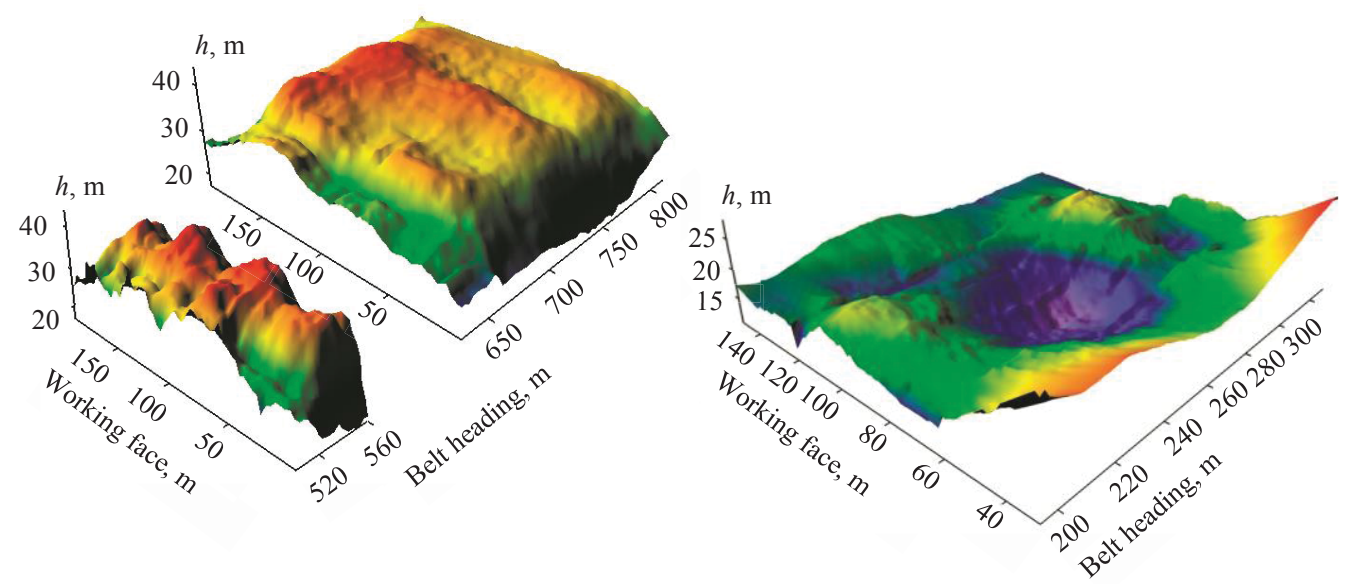

Fig. 2. Height of the rock layer exerting pressure on the longwall support

Рис. 2. Высота слоя пород, оказывающего давление на крепь лавы

The undermined disintegrated rock mass is presented at the vertical diagram in the form of displacement arches hierarchy, the height of which determines the thicknesses of the geomechanical layers. The parameters of the displacement arches are determined from the mined bed towards the daylight surface.

Rock mass disintegration process originates at the mined bed with the formation of arches with a minimum sizes of $h_{0}$ and $l_{0}$ (not shown at fig. 3), then, in the vertical direction, arches 1 are developed; after that, arches 2 are formed, indicated by the dashed line; the process is finished with arches 3, which reach the daylight surface (fig. 3).

Minimum dimensions $l_{0}$ and $h_{0}$ of arches-paraboloids are calculated by the formulae, $\mathrm{m}$ :

$$
l_{0}=\frac{l_{w f}}{2^{n}} \approx \frac{L_{1}}{4} \approx L_{2} ; \quad h_{0}=l_{0} / 2,
$$

where $l_{0}$ is the foundation diameter of the minimum arch, which is accepted as close to secondary caving step and multiple of the length of the working face, $\mathrm{m} ; l_{w f}$ - the length 
of the working face, $\mathrm{m} ; n$ - the level of the structural hierarchy (an integer), it is determined based on the condition $L_{1} / L_{2} \approx 4 ; L_{1}$ and $L_{2}-$ steps of the primary and secondary caving of roof rock correspondingly, m (either determined by the known dependences in the Interim Guidance on the Primary and Subsequent Steps of Roof Rock Caving when Mining Coal Beds with a Room and Pillar Method along the Strike in the Conditions of Kuzbass. 973. 27 p. or specified according to the mining and technological data); $h_{0}$ - the height of the minimum arch, $\mathrm{m}$.

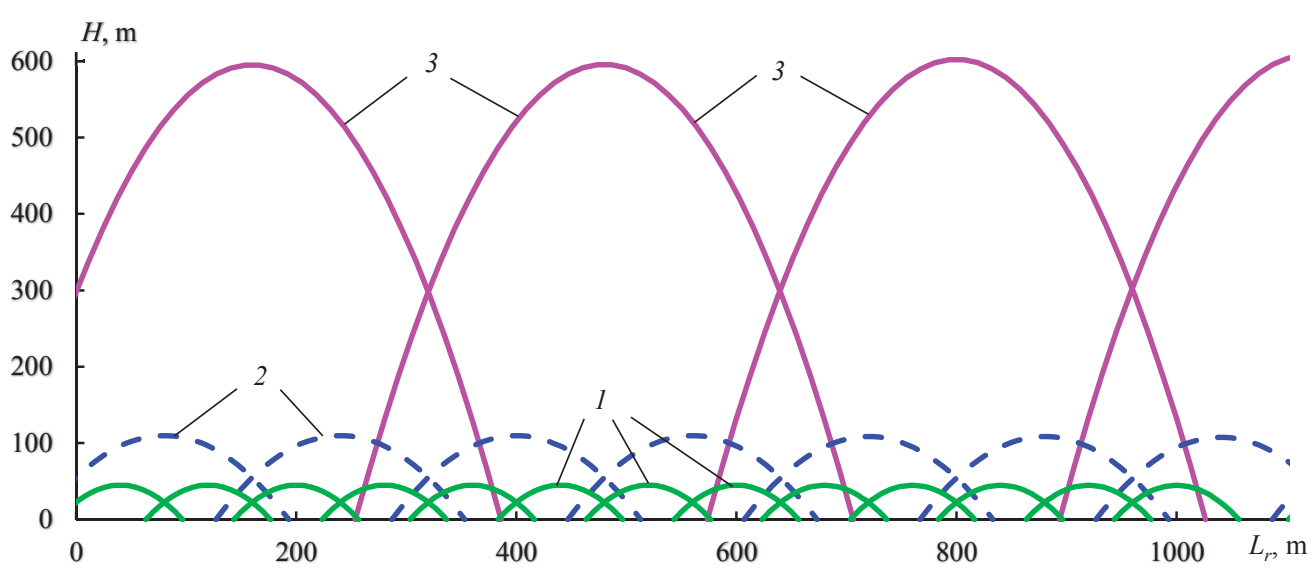

Fig. 3. Vertical structure diagram of the disintegrated rock mass: 1 - $\operatorname{arches} n_{3} ; 2$ - arches $n_{4} ; 3$ - arches $n_{5}$

Рис. 3. Вертикальная схема структуризации дезинтегрированного массива: 1 - своды $n_{3} ; 2$ - своды $n_{4} ; 3$ - своды $n_{5}$

The diameter of the $n$-level arch according to the structural hierarchy, m:

$$
l_{n}=l_{0} 2^{n} .
$$

The height of the $n$-level arch according to the structural hierarchy (with the account of the elastic energy of the mass), $\mathrm{m}$ :

$$
h_{n}=h_{0} 2^{n} E n,
$$

where $E n$ - is rock elastic energy spent to form the volumetric surfaces of archesparaboloids and dismember the corresponding masses, MJ.

Rock elastic energy is determined as a nonlinear function, $\mathrm{MJ}$ :

$$
E n=\varphi(k, H, E),
$$

where $k$ is the coefficient of the lithological pressure, MPa; $H$ - the depth of the mined bed occurrence, $\mathrm{m} ; E$ - rock elasticity modulus, MPa.

Results. As it is shown at fig. 2, the magnitude of active rock layer thickness is limited to $45 \mathrm{~m}$. It should be stated that this layer exerts direct pressure on the powered support, i.e. it is the thickness of the disintegrated rock layer, the power of which is carried by the powered support. The presented data meet the diagram of rock disintegration. It is known that the main superstrata pressure upon the near-face rock mass is carried by the coal bed. Geomechanical structure diagram shows the sequence of disintegrated rock displacement arches formation. The magnitudes of arch foundations are multiple of the length of the working face [15]. Within the limits of the arches, the load will be equal to the weight of the disturbed rock within, and the load 
falls upon the support of the longwall, while between the forming arches, rock pressure acts on the coal bed, and it will be equal to the value of overburden rock pressure plus the bearing pressure which is often 3-4 times as large as the overburden pressure. The amount of the overburden and bearing pressure depends on the depth of coal bed occurrence, working face advance rate, $\mathrm{m} /$ day, and roof rock strength. It is the sum of the overburden and bearing pressure that is reflected on the state of the coal bed ahead of the face of the longwall; their impact is wave-like. Coal sloughing develops, and coal bed cutting resistance alternates along the length of the working face.

Summary. Rock pressure alternation values determination along the length of the longwall will make it possible to eliminate its negative effect and plan the capacity of the cutter-loader and the load of the working face in various mining and geological conditions more reasonably. The method of controlling rock pressure is proposed at the longwall face when mining gently-sloping coal beds by the room and pillar method with roof cave-in; the method includes the construction of geomechanical structure diagram of coal-bearing disintegrated rock mass in the form of the hierarchy of geomechanical layers, the thickness of which corresponds to the height of the forming displacement arches, and it is distinguished by the fact that the constructed diagram will make it possible to forecast the sites of the increased rock pressure upon the coal bed and the support of the longwall face.

\section{REFERENCES}

1. Shadrin A. V., Klishin V. I. The improvement of automated dynamic phenomena forecast methods during roof weakening and preventive hydrotreating. Vestnik Nauchnogo tsentra VostNII po promyshlennoi $i$ ekologicheskoi bezopasnosti $=$ Bulletin of Scientific Center VostNII for Industrial and Environmental Safety. 2017; 3: 31-35. (In Russ.)

2. Tailakov O. V., Utkaev E. A., Smyslov A. I., Kormin A. N. Physical modelling of coal seams filtration properties fluctuation. Vestnik Kuzbasskogo gosudarstvennogo tekhnicheskogo universiteta = Kuzbass State Technical University Journal. 2014; 6(106): 13-16. (In Russ.)

3. Jacobi O. Rock pressure control practice. Translated from German. Moscow: Nedra Publishing; 1987. (In Russ.)

4. Bieniawski Z. Rock pressure control. Translated from English. Moscow: Mir Publishing; 1990. (In Russ.)

5. Zhou H., Liu H., Hu D., Zhang F., Yang F., Lu J. Estimation of the effective thermal properties of cracked rocks. European Journal of Environmental and Civil Engineering. 2016; 8: 954-970.

6. Xuan D. Y., Wang B. L., Xu J. L. A shared borehole approach for coal-bed methane drainage and ground stabilization with grouting. Int. J. Rock Mech. Min. Sci. 2016; 86: 235-244.

7. Litvinskii G. G. Stress-strain state of rock massif around longwall. Sbornik nauchnykh trudov Donbasskogo gosudarstvennogo tekhnicheskogo universiteta $=$ DonSTU Scientific Works Collection 2016; 3 (46): 16-24. (In Russ.)

8. Kasianenko A. L. A new construction for keep the stability of floor rocks in mine roadway. Problemy gornogo davleniia $=$ Problems of Rock Pressure. 2016; 2(29):17-26. (In Russ.)

9. Shinkevich M. V., Kozyreva E. N. Interrelations of the main features of the processes of unloading and shifting of the surrounding rocks with the dynamics of methane emission from the mined bed during longwall extraction. Vestnik Kuzbasskogo gosudarstvennogo tekhnicheskogo universiteta $=$ Kuzbass State Technical University Journal. 2006; 6: 17-19. (In Russ.)

10. Polevshchikov G. Ia., Shinkevich M. V., Plaksin M. S. Gas-kinetic features of the carbon methane decomposition on the belt heading of the working area. Gornyi informatsionno-analiticheskii biulleten (nauchno-tekhnicheskii zhurnal) = Mining Informational and Analytical Bulletin (scientific and technical journal). 2011; 8: 21-28. (In Russ.)

11. Roiter M., Kurfiust V., Mairkhover K., Veksler Iu. Undulant rock pressure distribution along a longwall face. Fiziko-tekhnicheskie problemy razrabotki poleznykh iskopaemykh = Journal of Mining Science. 2009; 2: 38-45. (In Russ.)

12. Pozin E. Z. Variability of the coal resistance to destruction by cutting. In: Destruction of rocks by mechanical means. Moscow: Nedra Publishing; 1966. p. 91-97. (In Russ.)

13. Pozin E. Z. Studying sloughing effect on coal resistance to cutting. In: Rock resisting power when mining. Moscow; 1962. p. 47-53. (In Russ.)

14. Chekhmesterenko N. V. Alterability of coal sloughing along the length of the working faces. Ugol = Coal. 1992; 6: 3-7. (In Russ.)

15. Shinkevich M. V., Leontieva E. V. Simulation of enclosing rock mass technological structuring during coal face operations. Vestnik Kuzbasskogo gosudarstvennogo tekhnicheskogo universiteta = Kuzbass State Technical University Journal. 2015; 3: 23-31. (In Russ.) 


\title{
Information about authors:
}

Maksim V. Shinkevich - PhD (Engineering), senior researcher, Institute of Coal, Federal Research Centre of Coal and Chemistry SB RAS. E-mail: max-valerich@rambler.ru

\section{Изменчивость горного давления по длине очистного забоя}

\author{
Шинкевич М. В. ${ }^{1}$ \\ ${ }^{1}$ Институт угля Федерального исследовательского центра угля и углехимии СО РАН, Кемерово, \\ Россия.
}

\begin{abstract}
Peфераm
Введение. Повсеместное углубление горных работ вызывает сложности с сохранением достигнутого уровня добычи. Возникают вопросы о способности механизированных крепей выдержсиать горное давление в таких условиях. Оснащение современных крепей датчиками давления позволит контролировать и предотвращчать негативное влияние повышенного горного давления и визуализировать результатьл.

Цель работы. Определение величин изменений горного давления по длине лавы, чтобы избежать его негативного влияния и более обоснованно планировать производительность комбайна $и$ нагрузку на очистной забой в разных горно-геологических условиях.

Методология. Использование программного продукта Surfer для визуализации процессов сдвижений $u$ построение схемы геомеханической структуризации углевмещающего дезинтегрированного массива горных пород в виде иерархии геомеханических слоев позволяет прогнозировать участки повышенного горного давления на угольный пласт и крепь длинного очистного забоя.
\end{abstract}

Результаты. Техническим результатом является заблаговременное и обоснованное определение участков повышенного горного давления на угольный пласт и мехазированную крепь при движении длинного очистного забоя.

Анализ и обсуждение. Схема геомеханической структуризаџии показывает последовательность формирования сводов сдвижений дезинтегрированных пород. На пласт угля между сводами сдвижений действует геостатическое и опорное давление, которое зависит от глубины залегания угольного пласта, скорости движения очистного забоя, крепости пород кровли. Именно суммарно геостатическое и опорное давление отражаются на состоянии угольного пласта впереди забоя лавы, и их влияние волнообразно.

Выводы. Построение схемы позволит прогнозировать участки негативного влияния горного давления по длине лавы, повысить эффективность отработки пласта угля за счет более точного расчета нагрузки на очистной забой и прочзводительность комбайна, уточнять усилие рабочих органов горно-выемочных машин при разрушении пласта угля, выбирать крепь лавы по несущей способности, планировать на определенных участках мероприятия по устранению негативного влияния горного давления, укреплять краевую часть пласта для снижения видимого отжима угля.

Ключевые слова: горное давление; угольный пласт; вмещающий массив; горные породы; длинный очистной забой.

\section{БИБЛИОГРАФИЧЕСКИЙ СПИСОК}

1. Шадрин А. В., Клишин В. И. Совершенствование методов автоматизированного прогноза опасности проявления динамических явлений в процессе разупрочнения кровли и профилактической гидрообработки угольных пластов // Вестник Научного центра ВостНИИ по промышленной и экологической безопасности. 2017. № 3. С. 31-35.

2. Тайлаков О. В., Уткаев Е. А., Смыслов А. И., Кормин А. Н. Физическое моделирование изменения фильтрационных свойств угольных пластов // Вестник Кузбасского государственного технического университета. 2014. № 6(106). С. 13-16.

3. Якоби О. Практика управления горным давлением: пер. с нем. М.: Недра, 1987. 566 с.

4. Бенявски 3. Управление горным давлением: пер. с англ. М.: Мир, 1990. 254 с.

5. Zhou H., Liu H., Hu D., Zhang F., Yang F., Lu J. Estimation of the effective thermal properties of cracked rocks // European Journal of Environmental and Civil Engineering. 2016. Iss. 8. P. 954-970.

6. Xuan D. Y., Wang B. L., Xu J. L. A shared borehole approach for coal-bed methane drainage and ground stabilization with grouting // Int. J. Rock Mech. Min. Sci. 2016. No. 86. P. 235-244.

7. Литвинский Г. Г. Напряженно-деформированное состояние массива горных пород вокруг лавы // Сборник научных трудов Донбасского государственного технического университета. 2016. № 3(46). C. 16-24.

8. Касьяненко А. Л. Новый способ обеспечения устойчивости пород почвы выемочных выработок // Проблемы горного давления. 2016. № 2(29). С. 17-26. 
9. Шинкевич М. В., Козырева Е. Н. Взаимосвязи основных особенностей процессов разгрузки и сдвижения вмещающих пород с динамикой выделения метана из разрабатываемого пласта при его отработке длинными выемочными столбами // Вестник Кузбасского государственного технического университета. 2006. № 6. С. 17-19.

10. Полевщиков Г. Я., Шинкевич М. В., Плаксин М. С. Газокинетические особенности распада углеметана на конвейерном штреке выемочного участка // ГИАБ. 2011. № 8. С. 21-28.

11. Ройтер М., Курфюст В., Майрховер К., Векслер Ю. Волнообразное распределение горного давления вдоль забоя лавы // ФТПРПИ. 2009. № 2. С. 38-45.

12. Позин Е. 3. Изменчивость сопротивляемости угля разрушению резанием // Разрушение горных пород механическими способами. М.: Недра, 1966. С. 91-97.

13. Позин Е. 3. Исследование влияния отжима на сопротивляемость угля резанию // Сопротивляемость горных пород разрушению при добывании. М., 1962. С. 47-53.

14. Чехместеренко Н. В. Изменчивость отжима угля по длине очистных забоев // Уголь. 1992. № 6. C. 3-7.

15. Шинкевич М. В., Леонтьева Е. В. Моделирование техногенной структуризации вмещающего массива горных пород при ведении очистных работ // Вестник Кузбасского государственного технического университета. 2015. № 3. С. 23-31.

\section{Сведения об авторах:}

Поступила в редакцию 18 декабря 2019 года

Шинкевич Максим Валериевич - кандидат технических наук, старший научный сотрудник Института угля Федерального исследовательского центра угля и углехимии СО РАН. E-mail: max-valerich@rambler.ru

Для цитирования: Шинкевич М. В. Изменчивость горного давления по длине очистного забоя // Известия вузов. Горный журнал. 2020. № 3. C. 24-30 (In Eng.). DOI: 10.21440/0536-1028-2020-3-24-30 For citation: Shinkevich M. V. Variability of rock pressure along the length of the working face. Izvestiya vysshikh uchebnykh zavedenii. Gornyi zhurnal = News of the Higher Institutions. Mining Journal. 2020; 3: 24-30. DOI: 10.21440/0536-1028-2020-3-24-30 